\title{
THE 'ASSIMILATION' YEARS IN A COUNTRY TOWN
}

\author{
Jo Woolmington
}

In a recent article on the Aboriginal-Australian Fellowship in which he reminisces about a journey from Sydney to Tingha, Jack Homer wrote, 'Just why a single-minded concern for Aborigines should have siezed so many middle-class white people in Australia in the 1950s is a mystery. You might call it a miracle'. 1

Whether the interest shown in the city of Armidale was a mystery is doubtful. It was almost too inevitable to be called a miracle. The development of the University of New England had attracted people not only from the capital cities, with little experience of Aborigines, but also people from other countries with no experience of them at all. These Australian and overseas newcomers were shocked by the living conditions of the Aborigines located as they were on the fringes of the town rubbish dump ${ }^{2}$ in 'houses' made of hessian bags, sheets of corrugated iron and cardboard boxes. The normal facilities of town life water, sewerage and electricity - were non-existent. Few white people visited these 'houses' but no-one could be ignorant that they were there. Nor could they be unaware of Aborigines visiting the town, or of Aboriginal children attending the schools. The effect was to make these white newcomers feel that something simply had to be done, but no-one knew quite where to begin.

It was at this time that an organisation was formed of women academics and wives of academics, known as the University Women's Association. Several of its members were women who had already looked at the possibility of doing something for the local Aborigines. They suggested that this could be a worthwhile project for the Women's Association to take up. There was some very strong opposition from within the organisation, however, from members who wished it to be solely a social group. Not only did they express opposition to becoming involved in what they saw as welfare work, but some also felt uncomfortable that long-term residents of the New England area might be offended at the implied criticism of their treatment of the Aborigines. The meeting was persuaded to reject the idea.

A visit not long after from the writer Kylie Tennant provided a catalyst. Hearing of her visit, several University women arranged to meet her and discuss the matter, telling of their interest in the Aborigines and their feelings of impotence about the problem. Her response was immediate; she suggested they visit the 'Dump' with her.

What they saw that day filled them with a sense of horror and a feeling that here was a matter calling for their urgent attention. During that visit they met and spoke to several Aboriginal women.

Soon after this, on 27 October 1956, a group of 28 people met at the home of Professor and Mrs Jackson to discuss the problem. They formed themselves into an

Jean (Jo) Woolmington teaches History at the University of New England. She is interested in race relations in colonial societies and in the role played by missionaries in cultural colonisation.

1 Homer 1987:33.

2 This dump was on Crown land just outside the town boundaries and within the boundaries of Dumaresq Shire. 
organisation which they called the Armidale Association for the Assimilaton of Aborigines, to be known as the AAA. ${ }^{3}$ The usual officers were elected, a Management Committee formed, and several people were given specific tasks such as approaching the local Member to enquire about the availability of Housing Commission homes, finding out about Far West holidays for Aboriginal children and collecting toys for the coming Christmas. The membership subscription fee was set at five shillings. Formation of the Association was reported in the local newspaper, where the aims of the group were said to include 'cooperation with other interested bodies to investigate the housing needs of the local aboriginal families and ameliorate them where possible, and the giving of assistance by personal contact where needed'. 4

The use of the term 'Assimilation', which was later to come into disrepute, was a perfectly acceptable one at the time. The idea had originally been adopted in 1937 at the first of the conferences called by the Federal Government between Federal and State Aboriginal Departments. The Second World War intervened and it was not until the 1950 s that the idea was oficially adopted. ${ }^{5}$ In October $1951, \mathrm{Mr}$ (later Sir) Paul Hasluck reported to the House of Representatives that the Native Welfare Conference held in the previous month had agreed

...that assimilation is the objective of native welfare measures. Assimilation means in practical terms, that, in the course of time, it is expected that all persons of aboriginal blood or mixed blood in Australia will live like white Australians do. The acceptance of this policy governs all other aspects of native affairs administration. 6

Assimilation thus became official government policy and this unambiguous aim was confirmed a decade later at the Native Affairs Conference of 1961.

...Aborigines and part-Aborigines are expected eventually to attain the same manner of living as other Australians and to live as members of a single Australian community enjoying the same rights and privileges, accepting the same responsibilities, observing the same customs and influenced by the same beliefs as other Australians. ${ }^{7}$

Assimilation thus assumed the complete absorption of the Aborigines into the wider Australian community, both sccially and economically. What it also assumed, while not spelling it out, was that Aborigines would willingly abandon their own culture and possibly their own people for the 'superior' European way of living. The Armidale group do not appear to have questioned this. Their Constitution stated that,

The ultimate aim of the Association shall be the acceptance of all Aboriginal people into the Australian community on the basis of complete equality with the other members of that community.

There is evidence that the AAA was able to put this theory into practice from the earliest days of its existence. While no Aborigines attended the foundation meeting, a month later

3 The word 'Assimilation' was dropped in 1965, but the initials remained the same.

4 Armidale Express, 2 November 1956.

5 Rowley 1971:25.

6 Extract from speech delivered to House of Representatives, 18 October 1951, quoted in Stone 1974.

7 Native Welfare Conference, Commonwealth and State Authorities: Proceedings and Decisions, January 1961, quoted in Rowley 1971:399. 


\section{ASSIMILATION IN A COUNTRY TOWN}

an Aboriginal woman undertook to make enquiries about a possible meeting room at the Police Boys' Club. 8

There was little opposition to the concept of assimilation because it was believed that most of the Aborigines' problems would be overcome once they were assimilated into European society. As citizens they would qualify for the benefits and rights of citizenship. That was a most desirable aim as far as the Armidale group was concerned. It was only later that people began to question the concept on the grounds that it would negate traditional Aboriginal culture. The AAA was also to find that there were elements within the local white population of Armidale who would not approve of assimilation if it meant that Aborigines were to become their close neighbours.

The Management Committee met for the first time on 31 October 1956 when a subcommittee was formed to investigate the possibility of establishing a handicraft industry for the Aborigines of the district. Another meeting on 20 November 1956 looked at the report of this sub-committee and discussed its recommendations including the buying or hiring of a knitting machine and looms, and instructing Aboriginal women and girls in the use of these. The resulting products would be sold by the Association. ${ }^{9}$ A meeting a few days later agreed that the Association should purchase a knitting machine.

There was emphasis at the November meeting on the urgent need for decent housing. It was also decided to approach Dean Jones, the Anglican Dean of Armidale, to suggest that two Aboriginal boys could be billeted in St John's, the hostel run by the Church of England for country boys attending Armidale High School. ${ }^{10}$

Within a month of its formation the Association had 40 members, both Aborigines and whites, by far the largest groups being University academics and their spouses. There were 36 present at the first General Meeting of 27 November 1956. Several matters were discussed including the availibility of a room for hire in the town suitable for handicrafts, at a rental of fifteen shillings per week. Eighteen people, two of them Aborigines, undertook to donate a shilling a week towards this rental. ${ }^{11}$ There was some discussion on the Constitution of the Association.

Among the names of possible Patrons put forward was that of the anthropologist, Professor A.P.Elkin. ${ }^{12}$ It was also suggested that Dr Stanner should be invited to Armidale to address a study group on local Aboriginal issues.

One of the earliest projects was the setting up of a Relief Fund and a sub-committe to administer it. Its main aims were:

1. to establish and administer a fund for the relief of Aborigines in necessitious circumstances

2. to assist with medical, dental and other expenses for the restoration of health and wellbeing of Aborigines who could not otherwise afford necessary treatment.

Very early in the piece the Association divided its priorities into three categories housing, education and employment. Various people were delegated to make enquiries about housing from the Housing Commission, Davis Hughes the local Member of Parliament, and the Aboriginal Welfare Board. When a local Aborigine applied to the Association for help with a $£ 150$ deposit on a $£ 500$ house, their response was to delegate two people to

8 Minutes of the AAA, 27 November 1956.

9 Minutes of Management Committee Meeting, 20 November 1956.

10 The first boy was accepted into the Hostel two months later. Minutes of Management Committee Meeting, 25 January 1957.

11 Minutes of the AAA, 27 November 1956.

12 No Patrons appear to have been appointed. 
examine the house and report back to the Association. In due course they reported that the house was over-valued and would prove a severe liablity to any purchaser, the plumbing, fencing and sewerage all requiring urgent and expensive attention. ${ }^{13}$ While this project was therefore abandoned, it was decided that the main office bearers of the AAA should sign letters of support to accompany the man's application for a Housing Commission home. The Association would hold itself responsible for the initial payment and legal expenses. ${ }^{14}$

In May 1957 the Association for the Assimilation of Aborigines held its first Annual General Meeting where they were able to report that in the first six months of the Association's life they had found employment for several Aborigines; had helped establish a boy at St John's hostel assisting with his school uniform and other expenses; established a club room where whites and Aborigines met and had given practical help with several health problems. 15

There was some opposition in Armidale to all this activity because it was believed that more Aborigines would be attracted to the city in the hope of benefiting from the work of the Association. These predictions seemed to have come true when the Armidale City Council debated the problem of the shifting population of Aborigines at the 'Dump'. Alderman E.M.Wilson, a local doctor, said she was deeply concerned about the unhealthy conditions in which they were living, including lack of water, 'It is pitiable to see the state of the youngsters' she said, and she suggested that they should be asked to return to the places they came from. There was considerable discussion on the matter and one alderman, R.B.Madgwick, (who was also the Vice-Chancellor of the University) said: 'We may solve our problems by sending the squatters from one place to another, but we don't solve theirs. ${ }^{16}$

The result of this discussion was the setting up of a conference between the Armidale City Council, a representative from the Aborigines Welfare Board, the Armidale police and the AAA. This conference took place on 20 November 1957, and one outcome was that the Association issued a policy statement in January 1958 in which they said, among other things, that assimilation had to be started with those Aborigines who had already shown by their own initiative that they were ready for it.

That means that in Armidale, for instance, any house built for aborigines should go, not to the destitute people of the Dump, but to one of the eight or nine families who are in relatively steady employment and are capable therefore of properly using such a house. With adequate employment and good housing which they then pay for, the future is theirs to make for themserves without further assistance. 17

This was very much a part of the assimilation idea - Aborigines who had already embraced some European values were the most likely candidates to accept them all, to be drawn fully into white society, to become part of that society, and to be accepted by it.

The AAA's policy statement argued against separating the Aborigines from white society, and putting them out of sight in camps. Apart from the fact that the Aborigines themselves did not want this, the AAA argued that it was counter-productive:

16 Armidale Express, 18 September 1957.

17 Ibid., 29 January 1958. 


\section{ASSIMILATION IN A COUNTRY TOWN}

The whole programme of assimilation is one of helping the aborigineto the point where he can move in the general community without further assistance.

... the aborigine can only learn the ways of white society when he is in that society. Assimilation cannot even be commenced in segregation. 18

Not surprisingly, one of the priorities of the AAA was the provision of houses and in 1958 the Association's major project was the building of a house for rental to an Aboriginal family. The Association had already assisted with the furnishing of a house which had been built by volunteeer labour using donated materials. This had been done under the supervision of Father Francis Kelly and a group of concerned laity with the backing of Bishop Doody, the Roman Catholic Bishop of Armidale. 19 At the official opening of the house, Father Kelly said he was 'most grateful for the goodwill and encouragement' of the AAA. ${ }^{20}$ The President of the AAA, Edna McIntosh, also spoke at the function and praised Father Kelly's 'excellent example'.

A couple of months later the committee of the AAA, having raised enough money to buy a block of land, launched an appeal to build a house for an Aboriginal family. The Armidale Express of 22 March 1957 carried a large headline 'Proposal for Second House for Aborigines'. It reported that the AAA had received several tentative offers of raw materials and labour. Various fund raising activities were organised, one of the first of which was a concert in the Armidale Town Hall given by the Aboriginal tenor Harold Blair. The Armidale branch of the Apex Club was associated with the AAA in this appeal. The local Parliamentary member, Davis Hughes MLA drew a promise that 'If it is possible to do so' the State government would provide a $f$ for $f$ subsidy. 21

Not everybody approved of the idea, however, for just as the foundations were about to be laid, a petition opposing the house began circulating in East Armidale, where the house was to be situated. The current President of the AAA, Ken Long, assured the petitioners that the Association intended to build a house 'which will compare more than favourably with the general standards of housing in Armidale', it would not be a 'shack or shanty'. ${ }^{22}$

Following the publication of this statement, a correspondent using the alias 'Protest', explained that the objection was not to houses being built for Aborigines, but to the visitors such houses would attract with their 'foul language, drunken brawls, filthy habits and audacity' 23

An argument over this issue raged in the local newspaper for some days. One correspondent suggested that the AAA should have held a referendum throughout Armidale to seek approval for building a house for an Aboriginal family, instead of 'upsetting the peace of the community'. The writer claimed that

a move should be made to provide comfort for them outside the municipality in a settlement by themselves where they could be happiest, and provided this was done in the proper manner and place, quite a lot of assistance could be expected from sympathisers. From my experience of the aborigine nature,

\footnotetext{
18 Ibid.

19 Flood 1979:122-123.

20 Armidale Express, 23 January 1957.

21 Ibid., 30 October 1957.

22 Ibid., 3 January 1958.

23 Ibid., 6 January 1958.
} 


\section{ABORIGINAL HISTORY $1991 \quad 15: 1$}

they have no more desire to assimilate with the white race than we have to mix with them. 24

The Publicity Officer of the AAA pointed out that it would be appalling if citizens could not move within their own town without a referendum of the whole town, and added that the family selected to rent the house had been 'known and respected in Armidale for many years'. ${ }^{25}$ This episode had made it clear that the idea of assimilation was far from universally acceptable.

In spite of this opposition to housing Aborigines within the town boundaries, there was plenty of volunteer labour to complete the building of the house. This ranged from students who cleaned second-hand bricks, to a local solicitor who gave his time voluntarily to attend to all the legal aspects of the project. Building materials, plumbing supplies, windows, electrical fittings etc. were donated by firms and individuals. Someone even donated a load of firewood. ${ }^{26}$

The house in Chapel Street was officially opened by the Chief Secretary (C.A.Kelly) on 29 November 1958. A few days later he told the Legislative Assembly that the committee of the Armidale AAA was the greatest he had encountered in his ministerial work: 'No words of mine could express my admiration for that committee'. 27

Jack Horner, who happened to be in Armidale on the day the house was handed over to an Aboriginal family, described the ceremony almost thirty years later and wrote:

The idea of donating a new home for a good family was well-meaning and popular, full of whitefella notions that by changing the environment you change the human being. ${ }^{28}$

Perhaps, 30 years on, many of the original members of the AAA might agree with this interpretation of their actions. The words 'assimilation' and 'absorption' had become interchangeable by the $1950 \mathrm{~s}$, and absorption was only possible if Aborigines conformed to the 'norms' of Australian life. What better way than by providing them with a house? As Rowley has suggested, the policy of assimilation took on the status of 'some kind of divine plan', ${ }^{29}$ a plan which the AAA was working to fulfil.

Whatever their motives, however, it was obvious to the members of the AAA that there was still a very long way to go in housing the Aboriginal families of Armidale. Approaches were made to the Aborigines Welfare Board and although hopes were raised in 1959 they came to nothing because of a shortage of funds.

Matters were brought to a head by a tragedy. In February 1960 two Aborigines from the 'Dump' died and there was an outbreak of severe gastric illness among children living there. At the Coronial inquest descriptions were given of the appalling sanitary conditions, conditions which had been reported by the City Health Surveyor soon after the deaths had occurred. ${ }^{30}$ Then in the following October it was reported that four children had died and a further eleven were in hospital as a result of those dreadful living conditions. ${ }^{31}$ Davis

'Canvasser', Armidale Express, 24 January 1958.

25 Ibid., 27 January 1958.

26 Ibid., 28 November 1958.

27 Ibid., 3 December 1958. This house was eventually sold to the Aborigines Welfare Board, AAA, AGM, 1966:3.

Homer 1987:37.

Rowley 1986:116.

30 Armidale Express, 2 March 1960.

31 Ibid., 14 October 1960. 


\section{ASSIMILATION IN A COUNTRY TOWN}

Hughes, the local Member, addressed the Legislative Assembly on the matter, appealing for government help. The local newspaper published editorials on the case in two consecutive editions. The first editorial seemed to hold the AAA and other volunteer workers partly to blame for the tragedy:

The proper housing of Aborigines is not an Armidale task, and must never be accepted as such. It is because the people of this district have endeavoured to do something for these unfortunates that the present tragedy has arisen. ${ }^{32}$

The implication, though not clearly stated, seems to have been that if volunteers had kept out of the way, governments would have stepped in sooner.

The response of the AAA to the deaths of the children was to put a petition before the people of Armidale, calling on the Government of NSW to provide decent housing not only for the Aborigines of the Armidale district, but for all other Aborigines who lived in similar circumstance on the outskirts of country towns. On the first Saturday morning 1345 signatures were collected in the main street as people shopped, and a further 648 in various churches on the following day. ${ }^{33}$ The final figure was a little over 2680.34

While this petition was still doing the rounds of Armidale it was announced that the State Government was making $£ 25,000$ available to clean up the 'Dump', (which was now being called the 'Reserve'), put in sewerage and build several cottages for the Aborigines currently living there. This was an increase of $£ 18000$ on the sum of $£ 7000$ previously allocated for the building of four houses. The AAA announced that it would continue to collect signatures on behalf of Aborigines of other country towns - 'the problem is not solved simply by cleaning up the Armidale Dump. ${ }^{35}$

On the same day that this announcement was made, it was reported that the Armidale City Council and the Dumaresq Shire Council had begun the installation of sanitary units and that by the end of the day each Aboriginal family at the 'Dump' would have a toilet unit. ${ }^{36}$ The Armidale City Council had been requested by the Shire Council to supply these services, as the Shire did not have the facilities.

Discussions on the future of the 'Dump' or 'Reserve' took on a new urgency because with the planned extension of the City boundaries on 1 January 1961, its management would become the business of Armidale City Council. While debating this some members of Council came to the conclusion that a Welfare Officer should be appointed to supervise the settlement. Although Alderman Wilson seconded the motion calling for a Welfare Officer, she did not go along with the congratulatory message to the State Government for providing the money for extra Aboriginal housing. Far from helping the Armidale Aborigines, she argued that the lure of houses would draw Aborigines from all over the place. 'You will have masses of people coming', she said which in the long run would do little good for the local people.

Speaking in reply to the debate, Alderman K. Long, (a former President of the AAA and a member of the University administration) who had proposed the motion, acknowledged that the Government's willingness to spend money on the Reserve would bring its own problems for the Council:

32 Ibid.

33 Ibid., 17 October 1960.

34 Ibid., 26 October 1960.

35 Ibid., 19 October 1960.

36 Ibid. 
I think we are going to get very, very grave problems, and we are going to have to insist on quite different standards from what Dumaresq Shire insisted on. 37

Six months later, the announcement that a Welfare Officer had been appointed was made at the same time that the letting of a contract for the building of the fourteen houses was announced. ${ }^{38}$ The AAA took an interest in both the design for these houses and the material to be used, and a deputation from the Association visited the Chief Secretary to discuss these matters. As a result of their representations, it was decided that the new houses should be insulated, and that a bedroom doorway planned to open into the middle of the living room should be placed elsewhere. ${ }^{39}$

The Association also swung into action immediately to assist Aboriginal families who were to move into the houses. Two kinds of help were sought - aid with furniture and equipment, and longer term help with 'acclimatisation' once they moved into the homes. This was expected to take the form of help and advice about cleaning and general care of the houses. 40

Fourteen Aboriginal families moved into their new three-bedroomed houses on the Reserve in November 1961. As a couple of families had already moved into Housing Commission homes in the town, the original shanties were now vacant. They were bulldozed, and Mr D.G.Yates, the Aboriginal Welfare Officer announced that the Aboriginal Welfare Board planned to beautify the Reserve with a garden area and a children's park. ${ }^{41}$ It was from this time that the Aboriginal inhabitants referred to their new homes as 'Silver City', a name still used by some.

The Housing sub-committee of the Association was finally disbanded in December 1967, its surplus funds being divided between the General Fund (\$218.56) and the Relief Fund. 42

Housing was, of course, just one aspect of the AAA's assimilation programmes and several other projects were proceeding concurrently.

The very first project to be set up by the AAA was a social club. This was run weekly in the Literary Institute under the leadership of voluntary hostesses. The club was provided with sewing machines on which Aboriginal women were given sewing and dress-making lessons. It was reported at the end of the first year that many Aboriginal women attended the club regularly and declared that they wouldn't miss it for anything. ${ }^{43}$ At one stage this club ceased to function because of a shortage of people to run it but more volunteers were quickly found and the club continued to flourish. 44

From the earliest days of the AAA, Aboriginal health was on the agenda and one of the first programmes to be established was a baby clinic, where special attention was given to the diet of both babies and older children. ${ }^{45}$ In the AAA's Fourth Annual Report it was mentioned that the sister in charge of the clinic reported a steady increase in the number of

Ibid., 26 October 1960.

Ibid., 10 April 1961.

Ibid., 3 May 1961.

Ibid., 10 May 1961.

Ibid., 6 November 1961.

Minutes of the AAA, 11 December 1967.

Ibid., 4 September 1957.

AAA, Fourth Annual Report 1960-61:2.

Ibid., 6 December 1957. 


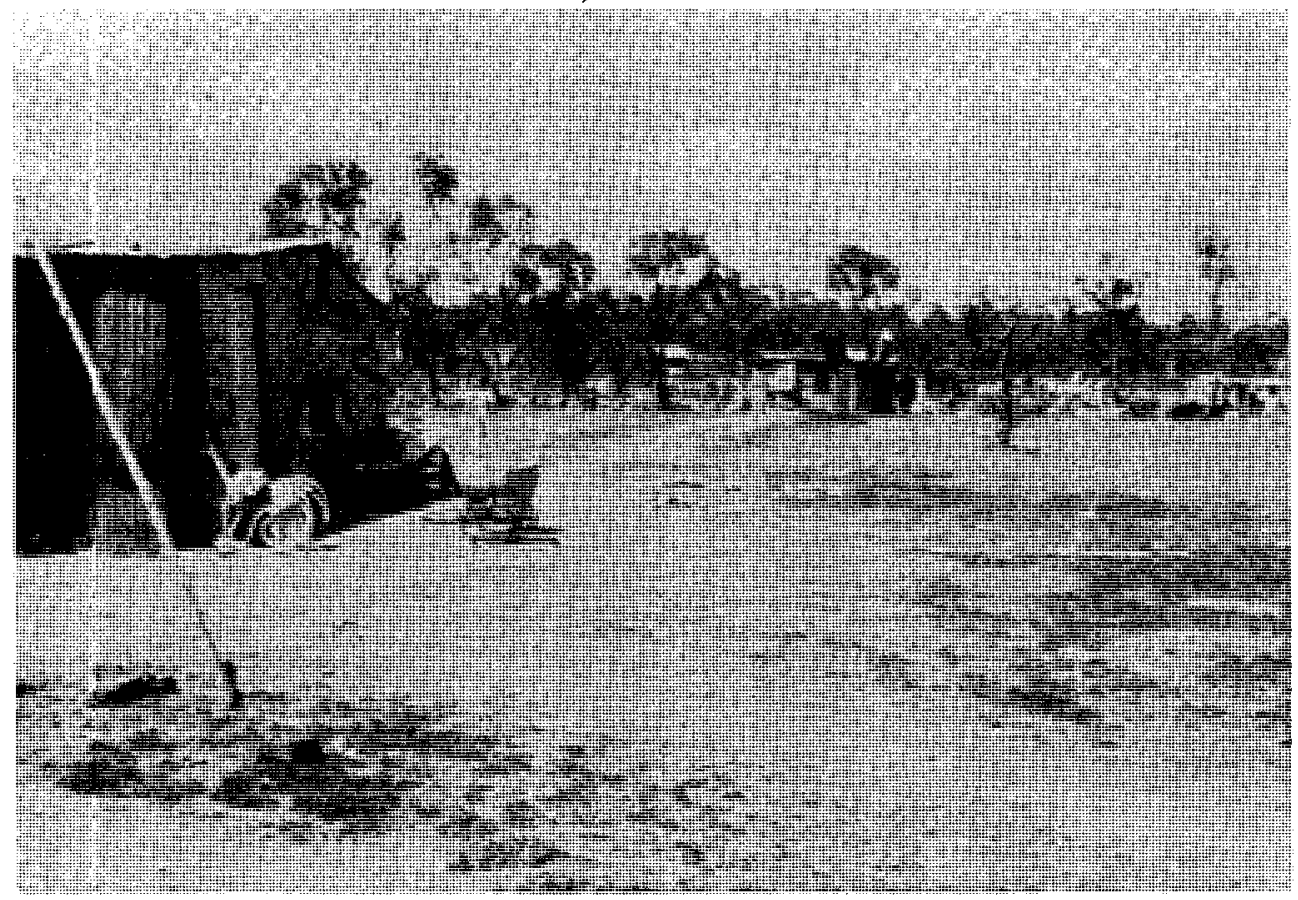

The 'Dump' as it was.

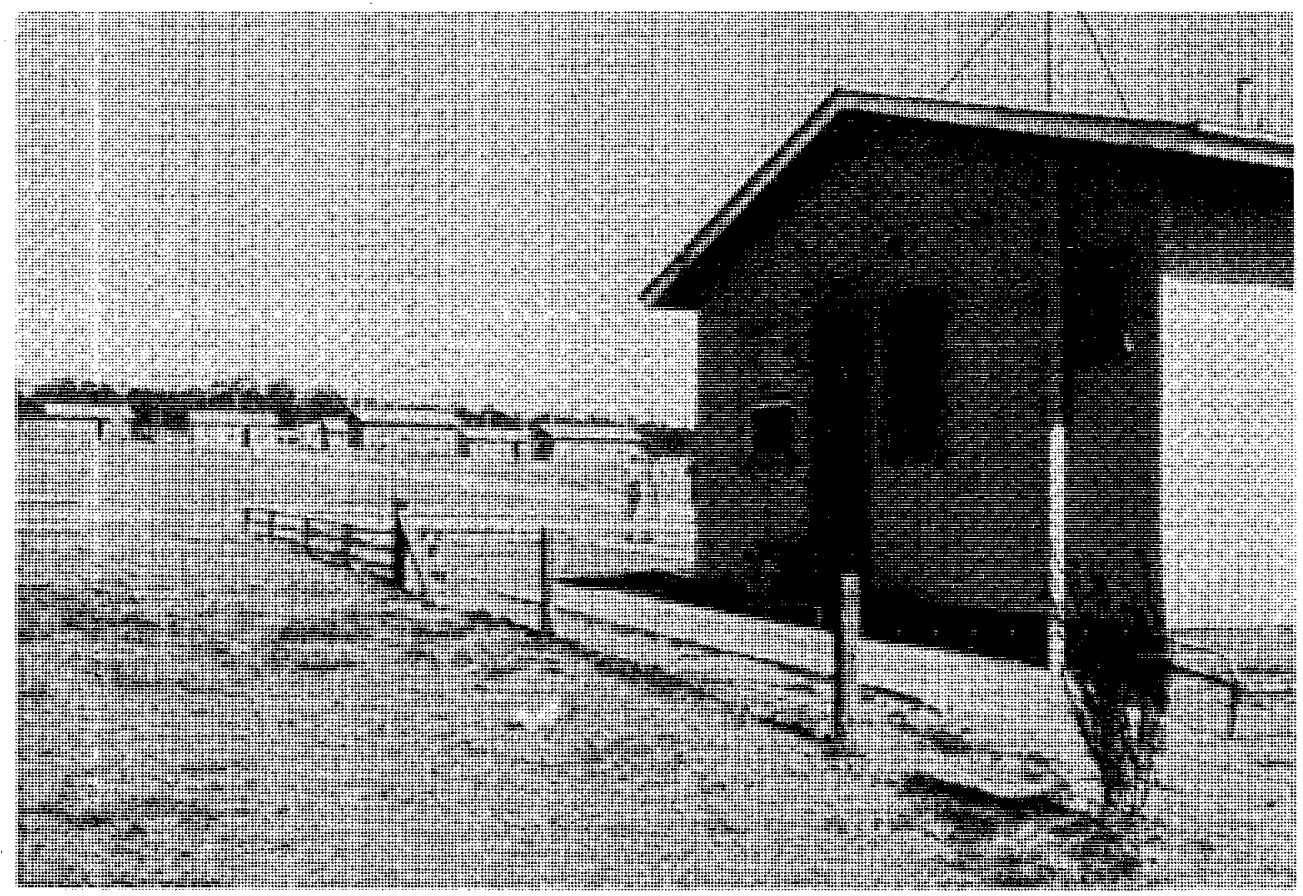

The new houses. 
Aboriginal mothers attending the clinic and an obvious understanding by them of what the clinic was trying to do. ${ }^{46}$ Proof of the clinic's success came when it was transferred to the official Baby Health Clinic attended by white families and the Aboriginal mothers continued to attend regularly, 47 although at the suggestion of the organiser, Florence Le Gay Brereton, a separate day was set aside to encourage their attendance. 48

Another project concerning young babies was the holding of an Aboriginal Baby Show in which sixteen babies were entered. Pictures of the winners and their mothers appeared in the local paper. 49

The Catholic Church in Armidale also organised social events designed to assimilate Aborigines into white society. Among these were regular dances and an annual Debutantes' Ball at which the Bishop or a visiting dignitary received the Debutantes. The local paper always carried reports of these functions with photographs. Eventually the Church discontinued the management of these events, as it was felt this smacked of white paternalism. Instead, they handed over a religious-cultural centre where the Aborigines could conduct their own social events. 50

Members of the AAA showed an early concern for education ranging from kindergarten to high school. The Association ran a kindergarten initially once a week, with occasional pauses when teachers left and had to be replaced. In May 1962 the AAA announced that one of its major aims was to get a permanent kindergarten established on the Reserve, and this came to fruition in September 1963 with the aid of the Save the Children Fund. ${ }^{51}$ The kindergarten is still running in 1991, with an Aboriginal teacher.

One of the chief means of helping high school children was to raise the necessary funds to enable them to live at the Church hostels and to help with school uniforms and books. One girl was coached to help her to sit for nursing entrance exams. ${ }^{52}$ The Association declared education to be a high priority with them in order to 'break the pattern' of poor employment, housing and esteem. ${ }^{53}$ One project was the conducting of a homework centre which students from the University supervised. ${ }^{54}$ In later years an individual tutoring system was set up with 160 tutors listed as available. 55

In 1969 the Association wrote to the Education Department deploring the lack of an Aboriginal culture component in the school syllabus, and recommending the setting up of a committee, which should include Aborigines, to formulate suitable syllabuses. 56

Perhaps the AAA's most consistent effort to assimilate the Aborigines of the Armidale district was to help them to find employment. At one of their earliest meetings they discussed practical ways of finding suitable jobs. 57 The University Registrar was

46

47

\section{8}

AAA, Fourth Annual Report 1960-61:1.

AAA, Fifth Annual Report 1961-62:6.

Information from Florence Le Gay Brereton.

Armidale Express, 25 November 1957.

Flood 1979:124.

Armidale Express, 25 September 1963.

Ibid., 4 September 1957.

AAA Second Annual Report 1958-59:2.

AAA Annual Report 1966:2.

AAA Minutes of meeting, 9 September 1970.

Ibid., 29 April 1969.

Ibid., 27 November 1956. 


\section{ASSIMILATION IN A COUNTRY TOWN}

approached, so was the Armidale City Council. 58 The Association was successful in getting some youths placed in apprenticeships. 59 An Employment Committe was established and was often able to report success. 60

Establishing Aborigines in decent houses, helping them to see their children through secondary school, getting them jobs, teaching them skills and introducing them to European-style social activities, were all part of 'assimilation'. There is little doubt that the Europeans thus engaged achieved considerable success, and formed many real friendships with the Aborigines of Armidale. But the time came when those Europeans realised that the Aborigines were ready and able to take over all these functions for themselves.

The time also came when the policy of assimilation itself began to be questioned. The Association's original ideas had been confirmed by a visiting anthropologist who told an Armidale gathering - 'The only way to assimilate the aborigines is to get them living among white people'.61 Aborigines themselves seemed to go along with this idea when several of them told a forum at the University of New England that they wanted to live in houses in the town 'like white people'.62

A different view was heard at a conference at the University in 1960 , the eminent anthropologist Professor A.P.Elkin raised doubts about the efficacy of assimilation. He said it was not acceptable to large numbers of Aborigines, particularly the mixed bloods. They took it to imply loss of their distinct grouping in the community, and sought more for integration of groups where they could retain their Aboriginal identity. With New Australians achieving integration in small groups rather than as individuals, the idea of integration was gaining credence. ${ }^{63}$

The matter of assimilation versus integration was discussed at the Annual General Meeting in 1964 when the President, Ralph Berman, raised doubts about integration. But in the following year's Report he spoke about the emergence of a committee formed among the Aborigines 'upon their own initiative' in which they discussed their own affairs and sought their own advancement, under the guidance of the Aborigines Welfare Board Officer and with a 'stiffening' of Europeans. 64

The whole of the 1965 Report was very optimistic in nature, but the President made one interesting prediction. He suggested that as the ability of Aborigines to stand on their own feet became evident, it could happen that the fear of competition could engender feelings of racism. 65

A special meeting was held on 4 May 1965 to consider a change of name for the organisation. A motion to rename the Armidale Association for the Advancement of Aborigines was amended to the Armidale Association for Aborigines, and the amendment was carried. The Secretary later explained:

the new name does not imply any change of aims or policies, it was merely

felt to be clearer and less pretentious. 66

58 Ibid., 20 February 1957 and 11 March 1957.

59

60 Armidale Express, 6 May 1959.

61 J.R.Beckett, reported in the Armidale Express, 30 April 1958.

62 Ibid., 25 May 1959.

63 Ibid., 30 May 1960.

64 AAA Annual Report 1965:1.

65 Ibid.:3.

66 Letter from Joan Boyd, 14 July 1965, AAA Correspondence. 


\section{ABORIGINAL HISTORY $1991 \quad 15: 1$}

The Association continued to do much the same work and was very active during the 1967 Referendum campaign. Yet the name change did, in fact, acknowledge that the organisation had accepted a change of emphasis in its activities. Assimilation was no longer the sought after goal; integration had become the preferred option.

In later years many members of the organisation preferred to see their role as a political pressure group, although they still involved themselves with local issues. 67

In December 1970 a notice was circulated inviting members to a 'Christmas' meeting, which would take the form of a discussion group to consider the proposed take-over of the Association by Aborigines. About 30 people attended this meeting, but as it was being treated as an informal gathering, no Minutes were taken, and no motions accepted.

For some time things had been moving towards a structural change in the organisation. Aborigines had been talking of taking the AAA over themselves, just as they were taking over similar progress associations throughout Australia at this time, and they were being encouraged by some white members who felt the purpose of the Association as far as Europeans were concerned, had run its course. This informal meeting was an outcome. In the months that followed, Aborigines began to run the AAA for themselves.

The Armidale Association had been a pioneer in the field of white-Aboriginal relationships. In the years following its foundation in 1956 it was approached by groups in many other country towns like Moree, Kempsey, Coffs Harbour and Bathurst seeking advice on setting up similar organisations. The Methodist Church of Australia sought information to put before its 1959 Queensland Conference. ${ }^{68}$ Perhaps some of this had to do with Armidale's status as a University city. While Armidale residents joined the AAA, it remained predominantly an organisation of University people. As well as dealing with day to day problems, they ran several conferences in association with the University's Adult Education Department. After one such conference which had been chaired by Professor Elkin, the Armidale Express published a letter with the bold headline, "Thank You, Educated Armidale'. 69

Measuring the 'success' or otherwise of the AAA is difficult. They were certainly successful in the field of housing and employment and to a lesser extent in the area of education. When the ideal of assimilation lost favour in the general commuity to be replaced by integration, most of the Aborigines of the Armidale area were certainly ready to take that in their stride. They had been assuming an increasing role in the running of their affairs over the years; they had also been showing increasing confidence in dealing with the European world.

Those fourteen fibro cottages have recently been replaced by brick houses under the auspices of the Land Council, and the settlement in now called 'Narwan' by the local Aborigines.

A recent volume gives the view of one Aboriginal woman who as a young mother attended the club run by the AAA and learned to make clothes for her children on the Club's sewing machine:

After the reserve was built and the cottages were built and we all moved in, it was a beautiful time then because everybody took pride in their homes and everybody had a beautiful garden. Some people say a lot against th'assimilation but I just wonder if those people went through what we went through. You wouldn't knock anyone that was tryin' to help yer. I know they

69 Letter from Mrs M. E. Plater of Maclean, Armidale Express, 3 June 1959. 


\section{ASSIMILATION IN A COUNTRY TOWN}

done a lot, the people of Armidale, th'assimilation people, it was all voluntary, they gave a lot of their time. Who gives up their time now without wantin' money to help blackfellers, eh? ${ }^{70}$

Discussing the whole episode recently with people who took part in the setting up and running of the Armidale Association for the Assimilation of Aborigines, I asked the question: 'Were they being hopelessly paternalistic?' There were several replies, one participant wondered if they were being unrealistic, even naive in trying to impart their white middle class ideas onto the Aborigines' life style. Florence Le Gay Brereton's was probably the most reassuring answer for those white middle classes: 'We did what seemed right at the time. To ignore the situation, to close our eyes to the way those people were living, - that would have been wrong.'

\section{BIBLIOGRAPHY}

Armidale Association for Aborigines, Archives.

Armidale Express

Cohen, Patsy and Margaret Somerville. Ingelba and the five black matriarchs. Sydney, 1990.

Flood, James Bernard. 'Bishop Doody and the Aborigines', Australasian Catholic Review 56(2), 1979:115-26.

Homer, Jack. 'From Sydney to Tingha: early days in the Aboriginal-Australian fellowship', Aboriginal History 11(1), 1987:33-40.

Rowley, C.D. Outcasts in white Australia: Aboriginal policy and practice. Canberra, 1971. Recovery: the politics of Aboriginal reform. Ringwood, Vic., 1986.

Stone, Sharman. Aborigines in white Australia: a documentary history of the attitudes affecting official policy and the Australian Aborigine, 1697-1973. South Yarra, Vic., 1974.

70 Cohen and Somerville 1990:101-102. 